\title{
Kuvvetin Etkileri Ünitesine Yönelik Geçerli ve Güvenilir Bilimsel Düşünme
}

\section{Alışkanlıkları Ölçeğinin Geliştirilmesi*}

\section{Hasan BAĞ $\breve{~}^{* *}$ ve Muammer ÇALIK ${ }^{* * *}$}

Öz: Fen okuryazarı birey yetiştirmenin ön koşullarından birisini de bilimsel düşünme alışkanlıklarının kazandırılması oluşturmaktadır. Bu çalışmada, ilkokul 4. sınıf fen bilimleri dersindeki kuvvetin etkileri ünitesine yönelik bilimsel düşünme alışkanlıkları ölçeğinin (BDAÖ) geliştirilmesi amaçlanmıştır. Bu amaç doğrultusunda, öncelikle ilgili alanyazın, ilkokul fen bilimleri ders kitapları ve 2018 fen bilimleri dersi öğretim programı detaylı şekilde incelenmiştir. Sonrasında ise kuvvetin etkileri ünitesi bağlamında bilimsel düşünme alışkanlıkları maddeleri geliştirilmiş ve madde havuzu oluşturulmuştur. Bir uzman grubu (fen eğitimcileri, Türkçe eğitimcileri ve sınıf öğretmenleri) ölçeğin kapsam geçerliğini, anlaşılabilirliğini ve uygulanabilirliğini değerlendirmiştir. Bunun yanısıra, beş 4. sınıf öğrencisi de ölçeği incelemiş ve ölçeğin anlaşılabilirliği ve uygunluğu hakkındaki görüşlerini bildirmişlerdir. Böylece, son hali verilen ölçek, 310'ar kişilik iki farklı gruba uygulanarak, açımlayıcı ve doğrulayıcı faktör analizlerine tabii tutulmuştur. Faktör analizi bulguları, ölçeğin madde yüklerinin yüksek olduğunu ve ölçek maddelerinin yedi faktörde toplandığını göstermiştir. Ayrıca, ölçeğin güvenirlik katsayısı (Cronbach alpha) değeri 757 olarak belirlenmiştir. Geçerli ve güvenirliği sağlanan ölçeğin ilkokul öğrencilerinin kuvvetin etkileri ünitesine yönelik bilimsel düşünme alışkanlıklarının belirlenmesinde kullanılması önerilmektedir.

Anahtar Kelimeler: Bilimsel düşünme alışkanlıkları, Dördüncü sınıf, Fen eğitimi, İlkokul, Kuvvetin etkileri.

\footnotetext{
* Bu çalışma, ikinci yazarın danışmanlığında birinci yazarın doktora tezinden üretilmiştir.

${ }^{* *}$ Arş. Gör. Dr. Recep Tayyip Erdoğan Üniversitesi, Eğitim Fakültesi, Temel Eğitim Bölümü, Email:hsnbag@gmail.com Orcid No: 0000-0002-6392-6834.

*** Prof. Dr., Trabzon Üniversitesi, Fatih Eğitim Fakültesi, Email: muammer38@hotmail.com, Orcid No: 0000-0001-83238783.
} 
Development of A Valid and Reliable Scientific Habits of Mind Scale for the 'Effects of

\section{Force’ Unit}

Abstract: One of the prerequisites for making people scientifically literate is to equip them with scientific habits of mind. The aim of this study was to develop the scientific habits of minds (SHOM) scale for the 'effects of force' unit in grade 4 science course. In this context, related literature, primary school science textbooks and the 2018 science curriculum were examined in depth. Later, based on the 'effects of force' unit, SHOM items were developed to yield an item-pool. A group of experts (science educators, Turkish educators and primary school teachers) evaluated the content validity, understandability and applicability of the scale. Also, five grade 4 students examined the scale and addressed their views of its understandability and suitability. Thus, the final version of the scale was administered to two different groups (310 by 310) for explanatory and confirmatory factor analysis. The findings of the factor analysis showed that the item loads of the scale were high and fell into seven factors. Furthermore, its reliability coefficient (Cronbach alpha) was found to be .757. The current study recommends that the valid and reliable scale can be used to identify primary school students' scientific habits of mind of the 'effects of force' unit.

Keywords: Scientific habits of mind, Science education, Primary school, Effects of force.

\section{Giriş}

Bilim ve teknoloji alanında yaşanan hızlı gelişmeler bilimsel düşünme kavramının öğretim programlarına daha fazla yansımasına sebep olmaktadır. Ülkemizde uygulanan fen bilimleri dersi öğretim programında da bu kavram Sosyobilimsel konuları kullanarak muhakeme yeteneği, bilimsel düşünme allşkanlıkları ve karar verme becerileri geliştirmek (s.9) şeklinde öğretim programının özel amaçları arasında kendisine yer bulmuştur (Milli Eğitim Bakanlığı, 2018). Dolayısıyla, öğrencilerin zenginleştirilmiş öğrenme ortamlarıyla fen konularını araştırma-sorgulamaya dayalı etkinliklerle öğrenmelerinin yanında üst düzey düşünme becerilerini (bilimin doğası, iş birliği, bilimsel süreç becerileri, argümantasyon, mantıksal muhakeme, bilimsel düşünme alışkanlıkları vb.) de geliştirilmeleri beklenmektedir (Bağ ve Çalık, 2017; Bybee, McCrae ve Laurie, 2009; Candaş, Kıryak, Kılınç, Güven ve Özmen, 2019; Ecevit ve Kaptan, 2019; Küçük, 2006; Sağdıç, Bakırcı ve Boynukara, 2019). Böylece, öğrenciler karar alırken ya da olguları analiz ederken bilimsel bilginin nasıl üretildiğini ve paylaşıldığını öğrenerek, bilimsel tutum geliştirebilme fırsatını yakalamış 
olurlar (Gauld, 1982). Nitekim, bilimsel tutumun geliştirilmesindeki rolü dikkate alındığında (Çalık ve Coll, 2012; Gauld, 1982), fen okuryazarı bireylerin yetiştirilmesindeki ön koşullardan birisini bilimsel düşünme alışkanlıkları (BDA) oluşturmaktadır (Çalık ve Coll, 2012).

BDA hem birbiriyle bağlantılı olan hem de bilimsel süreç becerileri, bilimin doğası ve argümantasyon gibi konularla yakından ilişkili olan yedi boyutu (mantıksallık, şüphecilik, inancın askıya alınması, otoriteden gelen argümana güvenmeme, açık fikirlilik, merak ve nesnellik) içermektedir (Çalık ve Coll, 2012; Gauld, 1982). Mantıksallık fikirlerin, kanıtların, inançların ya da sebeplerin birbirleriyle bağlantısını uygun argümanlarla açıklamayı ve bunların kanıtlar üzerinden gözden geçirilmesi ihtiyacını temsil etmektedir (Gauld, 1982; Storer, 1966). Başka bir açıdan bakıldığında, mantıksallık alışkanlığına sahip öğrencilerin argümanlarını kanıtlar 1şı̆̆ında sürekli gözden geçirmesi gerektiğinden, fen eğitiminde sıkça uygulanan argümantasyon süreci kanıt kullanımı bileşeniyle ortak özelliklere sahiptir (Erduran ve Jimenez-Aleixandre, 2007). Ayrıca bilimsel bilginin kanıtlarla desteklenmesi gerektiğinden (Lederman, 1998), bilim insanları mantıksallığı sıkça kullanmaktadır. Şüphecilik fikir ya da iddiaların hangi şartlar altında geçerli kabul edilebileceği konusundaki tutumları kapsamaktadır (Lederman, 1998). Aynı zamanda, şüphecilik kanıta dayanmayan iddialardan şüphe duymayı ve eleştirel sorgulamayı da gerektirmektedir (Çalık ve Coll, 2012). Dolayısıyla, şüphecilik argümantasyon sürecinin temel bileşenleri (iddia ve kanıt) arasındaki ilişkiyi yansıtmaktadır (Krajcik ve McNeill, 2015). Ínancın askıya alınması bir fikir ya da olguyla ilgili yeterli kanıt bulunmadığında karar alma sürecinin askıya alınmasını ifade etmektedir (Gauld, 2005). Dolayısıyla bir fikri desteklemek için aceleci davranmak yerine konuyla ilgili kanıtların toplanması ve gözden geçirilmesi gerekmektedir (Aikenhead, 1985; Holton, 1978). Otoriteden gelen argümana güvenmeme uzmanların üzerinde fikir birliği sağlayamadığı ve tarafların konu hakkında en az iki farklı fikri savunduğu durumları kapsamaktadır (Elby ve Hammer, 2001). Otorite kabul edilen kişilerin görüş ayrılığına düştügü konuları kapsaması nedeniyle, fen derslerinde ikileme düşüren ve tartışmalı konular olarak ele alınan sosyo-bilimsel konuların yapısına oldukça yakındır (Wiyarsi ve Çalık, 2019). Kesin bir çözümü ya da sonucu olmayan konular hakkında karar alırken, fikirlerin güvenirliğinin kanıtlar yardımıyla gözden geçirilmesini gerektirdiğinden yoğun bir argümantasyon sürecini de gerektirmektedir (Kolstø, Bungum, Arnesen, Isnes, Kristensen, Mathiassen ve Ulvik, 2006). Ayrıca otoritelerin farklı görüşleri karşısında oluşan güvensizlik duygusunu kapsadığından, şüphecilik boyutuyla da yakından ilişkilidir (Gauld, 1982). Açık 
fikirlilik bir başka bilginin de doğru olma ihtimalini göz önünde bulundurmayı ve yeterli kanıtlar sunulduğunda kişinin fikrini değiştirebilme alışkanlığına sahip olması gerektiğini ifade etmektedir (Hare, 1987, 2003; Rutherfort ve Ahlgren, 1990). Bilimsel bilginin kesin doğru olmayışının ve aksi kanıtlar sunulduğunda yanlışlanabilir oluşunun yeni fikirlere açık olmayı gerektirmesi, açık fikirlilik alışkanlığının bilimin doğasının öğretimindeki bir yansıması olarak değerlendirilebilir (Küçük, 2006). Merak doğuştan gelen öğrenme arzusunu, sorgulayıcı ve sistematik araştırma eğilimini içermektedir (Hodson, 2003). Bilimsel bilginin üretilmesi sürecinde hayal gücü ve yaratıcılık etkili olduğundan (Uluçınar-Sağır ve Kılıç, 2013), bilimsel araştırma süreciyle meşgul olan öğrencilerin merak duyguları sürekli canlı tutulabilir (Lederman, 1998). Nesnellik ise bilimsel araştırma sürecinde araştırmacının ön yargılarının olabildiğince kontrol altına alınmasıyla ve tarafsız davranma alışkanlığıyla ilgilidir (Gauld, 1982). Diğer yandan nesnellik, eldeki bulguların tekrarlanarak kontrol edilmesi ve bunların akran incelemesine sunulmasıyla sağlanacak objektif sonuçlara ulaşmayı da ifade etmektedir (Stanley ve Brickhouse, 1996). Bu anahtar özellikleri ve fennin diğer öğrenme boyutlarıyla/bileşenleriyle ilişkileri (örneğin; bilimin doğası, bilimsel süreç becerileri, argümantasyon vb) dikkate alındığında, fen okuryazarlık vizyonunun başarılmasında BDA'nın önemli bir yere sahip olduğu düşünülmektedir.

Son yıllarda BDA'nın fen eğitimi açısından önemi araştırmacılar tarafindan fark edilmiş ve bu alanda farklı bakış açılarını veya örneklemleri ele alan çalışmalar yapılmıştır. Örneğin; sosyo-bilimsel konular üzerinden öğretmen adaylarına (Çalık ve Coll, 2012) ve yetişkinlere (Wiyarsi ve Çalık, 2019) yönelik BDA ölçekleri geliştirilmiştir. Ayrıca, bu ölçeklerin kullanıldığı durum tespiti çalışmaları (Çalık, Turan ve Coll, 2014; Kolomuç ve Çalık, 2019; Wiyarsi ve Çalık, 2019) ve müdahale araştırmaları da yürütülmüştür (Çalık ve Cobern, 2017; Çalık ve Karataş, 2019). Bu araştırmaların bulguları, BDA'nın bir ya da birkaçının baskın olarak yansıtıldığını ve çekinik kalan boyutların da geliştirilmesi gerektiğini ortaya koymaktadır (Çalık vd., 2014; Çalık ve Cobern, 2017; Çalık ve Karataş, 2019; Kolomuç ve Çalık, 2019; Wiyarsi ve Çalık, 2019). Bu durum da, öğrencilerin BDA düzeylerinin erken yaşlardan itibaren belirlenmesini gerekli kılmaktadır (Bağ ve Çalık, 2018). Ancak, ilkokul düzeyinde BDA düzeyini belirlemeye yönelik geliştirilmiş bir ölçme aracının bulunmaması, bu alandaki önemli bir ihtiyacı göstermektedir.

Her ne kadar 2018 fen bilimleri dersi öğretim programı BDA'nın sosyobilimsel konular üzerinden geliştirilmesini önerse de mevcut çalışma sosyobilimsel konular kullanılmadan da fen konuları üzerinden (örneğin; kuvvetin etkileri ünitesi) BDA'nın 
boyutlarının ölçme aracına yansıtılabileceği düşüncesiyle ortaya çıkmıştır. Bu özelliğiyle sadece sosyobilimsel konuları kullanarak BDA ölçeğini geliştiren çalışmalardan bariz bir şekilde ayrışmaktadır. Örneğin; kuvvetin etkileri ünitesinde verilen "Miknatısin etki ettiği maddeleri deney yaparak keşfeder" kazanımı, öğrencilerin merak ve açı fikirlilik gibi bilimsel düşünme alışkanlıklarını harekete geçirmek için kullanılabilir. Benzer şekilde öğretim programında diğer BDA boyutlarını geliştirebilecek özelliklere sahip farklı kazanımlar da yer almaktadır. Bu çalışmada, ilkokul 4. sınıf fen bilimleri dersindeki kuvvetin etkileri ünitesine yönelik bilimsel düşünme alışkanlıkları ölçeğinin (BDAÖ) geliştirilmesi amaçlanmıştır.

\section{Yöntem}

$\mathrm{Bu}$ bölümde ölçek geliştirme sürecinin madde havuzu oluşturma, kapsam geçerliği, pilot uygulamalar ve faktör analizleri basamakları aşamalı olarak sunulmuştur.

\section{Madde Havuzu}

Mevcut çalışmada kuvvetin etkileri ünitesine yönelik Bilimsel Düşünme Alışkanlıkları Ölçeğinin (BDAÖ) geliştirilmesi amaçlandığından, madde havuzunda yer alacak maddeleri tasarlamadan önce ilgili alanyazın detaylı incelenmiştir. Bu kapsamda BDA ile ilgili alanyazında belirlenen boyutlar (mantıksallık, şüphecilik, nesnellik, otoriteden gelen argümana güvenmeme, inancın askıya alınması, açık fikirlilik ve merak) ve bunlara ait anahtar özellikler incelenmiştir. Ardından ilkokul 4. sınıf fen bilimleri dersindeki kuvvetin etkileri ünitesinin kazanımları ve ders kitaplarındaki ilgili konular incelenerek, madde havuzuna rehberlik edecek anahtar kavramlar listelenmiştir. Diğer yandan, daha önce lisans öğrencilerine (Çalık ve Coll, 2012) ve Endonezya halkına yönelik (Wiyarsi ve Çalık, 2019) sosyobilimsel konular bağlamında geliştirilen bilimsel düşünme alışkanlıkları ölçekleri yapısal olarak incelenmiștir. Madde yazımıyla ilgili ön hazırlıkların tamamlanmasının ardından, anahtar kavramlar doğrultusunda her BDA boyutunun anahtar özelliklerini yansıtan ortalama yedi madde yazılmışıı. Maddeler ilk olarak ilgili ünitenin kavramlarını kapsayan önermeler şeklinde tasarlanmış ve ardından ele alınan bilimsel düşünme alışkanlığının anahtar özelliğine vurgu yapılmıştır. Örneğin; kuvvetin hızlandıran ve yavaşlatan etkisi kavramına yönelik yazılan maddenin öncelikle kavramı doğru şekilde ifade etmesine (kalecinin topu hızlı ya da yavaş bir şekilde yuvarlaması) ve ardından mantıksallık boyutunun özelliğini yansıtmasına (topun hızlı veya yavaş olmasının mantıksal olarak topa uygulanan kuvvete bağlı olması) dikkat edilmiştir. Bu yolla ilgili madde hem ünitenin kavramlarını hem de ilgili BDA boyutunu kapsayacak şekilde tasarlanmıştır. Dolayısıyla, mantıksallık boyutunda 
yazılan bir maddede sebep sonuç ilişkisine dayanan (kalecinin topu hızlı ya da yavaş yuvarlaması, topa uyguladığı kuvvete bağlıdır) ifadeler kullanılmıştır. Bu ilişkinin tüm BDA boyutlarında yazılan maddelerde kurulmasına özen gösterilmiştir. Böylece BDAÖ için ünite kapsamındaki beş kazanımı içeren ve 38 maddeden oluşan taslak bir madde havuzu oluşturulmuş̧ur.

Duyuşsal özelliklerin nötr olamayacağı düşüncesi, Likert tipi ölçeklerde orta noktası olmayan çift sayıdaki derecelendirmelerin kullanılmasını daha fazla ön plana çıarmaktadır (Bursal, 2019). Bu düşünce dikkate alınarak, madde havuzunun ölçek formatına dönüştürülmesinde dörtlü Likert tipi derecelendirme kullanılmıştır. Ayrıca, bu derecelendirmelerde ilkokul öğrencilerinin yaş düzeyi göz önünde bulundurularak daha ilgi çekici olduğu düşünülen ve okuma sırasında zaman tasarrufu sağlayan yüz ifadelerinin kullanımı tercih edilmiştir. Bu kapsamda; "kesinlikle katılmıyorum" anlamında kızgın yüz (), "katılmıyorum" anlamında üzgün yüz (-), "kat1lıyorum" anlamında gülen yüz (:) ve "kesinlikle katılıyorum" anlamında mutluluktan uçan yüz (-) emojileri kodlanmıştır.

\section{Kapsam Geçerliği Çalışmaları}

Taslak BDAÖ'deki maddelerin ölçmek istediği amaca uygunluğunu belirlemek için kapsam geçerliği çalışması yapılmıştır (Fraenkel ve Wallen, 1996). Bu kapsamda ilk olarak taslak ölçme aracı, taşıdığı anlam bakımından hatalı olan ve tekrara düşen madde olup olmadığ 1 konusunda yeniden incelenmiştir. Ardından ünitenin içeriği, kazanımları ve BDA boyutlarının anahtar özelliklerine uygunluğu açısından tekrar gözden geçirilmiştir. Bazı BDA boyutlarına ait ifadelerin benzer ifadeler içerdiği ve öğrencilerin farklı boyutlardaki maddeler için benzer bilimsel düşünme sürecinden geçebileceği şüphesiyle, maddelerin yapısı BDA'nın anahtar özelliklerini daha fazla vurgulayacak şekilde "şüpheyle yaklaşırım, denemeler yapmadan inanmam, doğru olma ihtimalini dikkate alırım, merak ederim ve tarafsız olarak araştırılmasını beklerim" gibi ifadeleriyle desteklenmiş̧ir. Bu işlemlerin ardından, taslak BDAÖ kapsam geçerliğini sağlamak amacıyla bir grup uzmanın incelemesine sunulmuştur (Tablo 1).

Tablo 1. Görüşü alınan uzman listesi ve çalışma alanı

\begin{tabular}{|c|c|c|c|}
\hline Uzmanlar & & $\begin{array}{l}\text { İnceleyen uzman } \\
\text { sayısı }\end{array}$ & İnceleme kapsamı \\
\hline \multirow{2}{*}{ Fen eğitimi uzmanları } & Asil 3 & \multirow[t]{2}{*}{3} & \multirow{2}{*}{ BDA-ünite kazanımları ilişkisi } \\
\hline & Yedek 2 & & \\
\hline
\end{tabular}




\begin{tabular}{lllll}
\hline \multirow{2}{*}{ Türkçe eğitimi uzmanları } & Asil & 3 & 3 & Dil ve anlatım \\
\cline { 2 - 3 } & Yedek & 2 & 3 & \\
\hline Sinıf öğretmenleri & Asil & 3 \\
\cline { 2 - 3 } & Yedek & 2 & 3 & Öğrenci düzeyine uygunluk
\end{tabular}

Kapsam geçerliğini sağlamak amacıyla fen eğitimcilerinin, Türkçe eğitimcilerinin ve sınıf öğretmenlerinin görüşlerine başvurulmuştur. Her alandan seçilen 3 asil uzmana ulaşılamadığı durumda, yedek listesinde bulunan uzmanların görüşüne başvurulması planlanmıştır. Dolayısıyla her alandan toplam beş uzman belirlenmiştir. Fen eğitimi alanından görüşüne başvurulan uzmanlar, taslak ölçme aracındaki maddelerin ilgili üniteye ve BDA boyutlarına uygunluğunu değerlendirmiştir. Uzmanlara taslak maddelerle birlikte BDA anahtar özelliklerini kapsayan bir tablo verilerek maddelerle karşılaştırma yapmaları istenmiş ve maddelerin amaca uygun olduğu dönütü alınmıştır. Diğer yandan, ölçek maddeleri Türkçe eğitimcileri tarafından dil ve anlatım yönünden gözden geçirilmiştir. Türkçe eğitimcilerinin anlam bozukluğu barındıran maddelerin düzenlenmesi ve imla açısından uygun işaretlerin seçimi konusundaki dönütleri dikkate alınarak, maddelerde gerekli düzenlemeler yapılmıştır. Ayrıca, ölçek maddeleri sınıf öğretmenleri tarafından incelenmiş ve öğrenci düzeyine uygun olduğu konusunda dönütler alınmıştır. Son olarak, taslak ölçme aracı ilkokul 4. sınıfta okuyan beş öğrenciye uygulanarak, anlaşılmayan ya da ikileme düşüren madde olup olmadığ1 konusunda görüşleri alınmıştır. Bu çalışmalar sonucunda bazı maddelerin hem BDA boyutlarını temsil etmesi hem de öğrenci düzeyine uygunluğunu sağlamak açısından bazı düzenlemeler yapılmıştır. Örneğin; şüphecilik boyutunda hazırlanan "Dünyanın merkezinin bir çekim kuvveti olduğu söylemine inanmam için açıklayıcı bilgilere ihtiyacım var" maddesinin öğrenci düzeyine uygunluğunu sağlamak için madde "Dünyanın merkezinin doğal bir mıknatıs olduğu fikrine inanmam için daha açıklayıcı bilgilere ihtiyacım var” şeklinde düzenlenmiştir. Bu yolla maddenin kavramsal olarak daha açık ve anlaşı1ır hali yazılmış ve ilgili BDA'nın özelliğini daha iyi yansıtabilmesi için "daha açıklayıcı bilgilere ihtiyacım var" şeklindeki cümle yapısı kullanılmıştır. Benzer şekilde, inancın askıya alınması boyutunda yazılan "Okuduğum bir yazıda mıknatısın sadece metalleri çektiği yazıyorsa, bu konuda örnek uygulamalar görmeden inanmam" maddesi "Okuduğum bir yazıda mıknatısın sadece metalleri çektiği yazıyorsa, örnek uygulamalar görmeden bu bilginin doğruluğuna karar vermek için acele etmem" şeklinde düzenlenmiştir. Böylece, maddedeki anlam daralması 
giderilirken; "karar vermek için acele etmem" ifadesi eklenerek ilgili BDA'nın temsil gücü artırılmıştır. Uzman görüşleri ve öğrencilerin dönütlerine bağlı kalarak taslak ölçekte yapılan düzenlemeler sonrasında, 38 maddelik BDAÖ'nün pilot uygulamaya hazır hale geldiğine karar verilmiştir. Maddelerin ünite kazanımlarına ve kavramlarına göre dağılımı Tablo 2'de verilmiştir.

Tablo 2. Ölçek maddelerinin ünite kazanımlarına ve kavramlarına göre dağılımı

\begin{tabular}{|c|c|c|c|}
\hline Konu & Kazanımlar & Kavramlar & İlişkili maddeler \\
\hline \multirow{7}{*}{$\begin{array}{l}\text { Kuvvetin } \\
\text { Cisimler } \\
\text { Üzerindeki } \\
\text { Etkileri }\end{array}$} & \multirow{7}{*}{$\begin{array}{l}\text { F.4.3.1.1. Kuvvetin, cisimlere } \\
\text { hareket kazandırmasına ve } \\
\text { cisimlerin şekillerini değiştirmesine } \\
\text { yönelik deneyler yapar. }\end{array}$} & $\begin{array}{l}\text { Kuvvetin } \\
\text { hızlandırıcı etkisi }\end{array}$ & \multirow{7}{*}{$\begin{array}{l}\text { m1, m2, m5, m6, m7, } \\
\text { m9, m11, m14, m16, } \\
\text { m17, m19, m22, m29, } \\
\text { m30 }\end{array}$} \\
\hline & & \multirow{6}{*}{$\begin{array}{l}\text { Kuvvetin yavaşlatıcı } \\
\text { etkisi } \\
\text { Kuvvetin yön } \\
\text { değiştirici etkisi } \\
\text { Kuvvetin şekil } \\
\text { değiştirici etkisi }\end{array}$} & \\
\hline & & & \\
\hline & & & \\
\hline & & & \\
\hline & & & \\
\hline & & & \\
\hline \multirow{8}{*}{$\begin{array}{l}\text { Miknatısların } \\
\text { Uyguladığı } \\
\text { Kuvvet }\end{array}$} & F.4.3.2.1. M1knatıs1 tanır ve & \multirow{8}{*}{$\begin{array}{l}\text { Miknatıs } \\
\text { Miknatısın kutupları } \\
\text { Miknatısın kullanım } \\
\text { alanları }\end{array}$} & \multirow{2}{*}{$\mathrm{m} 3, \mathrm{~m} 4, \mathrm{~m} 27, \mathrm{~m} 28, \mathrm{~m} 31$} \\
\hline & kutupları olduğunu keşfeder. & & \\
\hline & F.4.3.2.2. M1knatısın etki ettiği & & $\mathrm{m} 8, \mathrm{~m} 12, \mathrm{~m} 13, \mathrm{~m} 15$ \\
\hline & maddeleri deney yaparak keşfeder. & & m18, m21, m35, m36 \\
\hline & $\begin{array}{l}\text { F.4.3.2.3. Mıknatısların günlük } \\
\text { yaşamdaki kullanım alanlarına } \\
\text { örnekler verir. }\end{array}$ & & $\begin{array}{c}\mathrm{m} 10, \mathrm{~m} 20, \mathrm{~m} 32, \mathrm{~m} 33 \\
\mathrm{~m} 38\end{array}$ \\
\hline & F.4.3.2.4. Miknatısların yeni & & \multirow{3}{*}{$\begin{array}{c}\mathrm{m} 23, \mathrm{~m} 24, \mathrm{~m} 25, \mathrm{~m} 26 \\
\mathrm{~m} 34, \mathrm{~m} 37\end{array}$} \\
\hline & kullanım alanları konusunda & & \\
\hline & fikirlerini açıklar. & & \\
\hline
\end{tabular}

\section{Pilot Uygulama}

Hazırlanan taslak BDAÖ pilot çalışma yapmak amacıyla 2017-2018 öğretim yılının bahar yarıyılında toplam 620 (açımlayıcı ve doğrulayıcı faktör analizlerinin her biri için 310 kişilik iki farklı grup olmak üzere) ilkokul 4. sınıf öğrencisine uygulanmıştır. Katılımcıların kuvvetin etkileri ünitesini işlemiş olması ön koşul olarak ele alınmış olup katılımcıların kolay ulaşılabilir ve gönüllü olmasına dikkat edilmiştir. Ayrıca, BDAÖ’nün uygulama süresi yaklaşık 25 dakika olarak belirlenmiş̧ir. 


\section{Faktör Analizi}

Faktör analizi, maddelerin dağılım gösterdiği en uygun faktör yapısını belirlemek ve varsayımların kontrol edilerek faktör uyum değerlerinin hesaplanması amacıyla açımlayıcı ve doğrulayıcı olarak iki aşamada gerçekleştirilmiştir (Koyuncu ve Kılıç, 2019). BDAÖ’nün faktör yapısını belirlemek amacıyla, birinci pilot uygulamada toplanan veriler açımlayıcı faktör analizine tabi tutulmuştur. Analiz sonrasında ağırlık değeri düşük olan ve belli bir faktör altında toplanmayan (dağınık halde bulunan) maddeler ölçekten çıkarılmıştır (18 madde). Geriye kalan maddelerin ağırlık değerlerinin beklenen değerler arasında olduğu ve uygun faktör yapısını oluşturduğu görülmüştür. Ardından ölçek ikinci gruba (310 öğrenci) uygulanarak faktör yapısının ilgili uyum iyiliği değerlerine göre uygun olup olmadığını belirlemek için doğrulayıcı faktör analizi yapılmıştır.

\section{Bulgular}

Bu bölümde, kuvvetin etkileri ünitesine ait BDAÖ’nün analiz bulguları verilmiştir.

\section{Açımlayıcı Faktör Analizi}

BDAÖ ile toplanan verilerin faktör analizine uygunluğu Kaiser Mayer Olkin (KMO) ve Barlett Testleri yardımıyla incelenmiştir (Kalaycı, 2010). Bu testlere ait sonuçlar Tablo 3'te sunulmuştur.

Tablo 3. BDAÖ’ye ilişkin KMO ve Barlett Testi sonuçları

Chi-Square

df

p
872.546

.000

Tablo 3'e göre, BDAÖ'nün KMO değeri 0.711 olarak belirlenmiştir. Faktör analizi için bu değerin 0.60 ve üzeri değerde olması beklendiğinden (Büyüköztürk, 2011), verilerin faktör analizine uygun olduğunu görülmektedir. Ayrıca, BDAÖ’nın ki-kare (Chi-Square) değeri 872.546; df değeri 190 ve p değeri .000 düzeyinde anlamlı bulunmuştur. Bu verilerden hareketle, ölçeğin faktör analizi için gerekli ölçütleri sağladığı söylenebilir.

BDAÖ maddelerinin faktörlere dağılımını incelemek amacıyla döndürülmüş bileşenler matrisi incelenmiştir. İlk verilere göre, maddelerin 12 faktöre dağınık bir şekilde yerleştiği görülmüştür. Madde ağırlık değeri 0.30'un altında kalan maddelerin ölçekten çıkarılması gerektiğinden (Büyüköztürk, 2011), bu kritere uymayan altı maddenin çıkarılmasına karar 
YYÜ Eğitim Fakültesi Dergisi (YYU Journal of Education Faculty), 2021; 18(2)1-24,http://efdergi.yyu.edu.tr,

verilmiştir. Ardından herhangi bir faktöre uymayan, tek başına bir faktör oluşturan ve aynı anda iki faktörde benzer madde ağırlık değeri gösteren (ağırlık değerleri arasındaki fark

0.1'den daha az olan) 12 madde de ölçekten çıkarılmıştır. Madde eleme işlemleri sonrasında BDAÖ'de kalan maddeler ve maddelerin ağırlık değerleri Tablo 4'te verilmiştir. 


\begin{tabular}{clc}
\hline $\mathrm{m} 1$ & $\begin{array}{l}\text { Oyuncak bir arabayı iterek oynadı̆̆ımda, onu kuvvetin yönü } \\
\text { doğrultusunda hareket ettirdiğim için kuvvet uygulamış olurum. }\end{array}$ & .594 \\
\hline $\mathrm{m} 5$ & $\begin{array}{l}\text { Bir kalecinin topu hızlı ya da yavaş yuvarlaması, topa uyguladığı } \\
\text { kuvvete bağlıdır. }\end{array}$ & .542 \\
\hline $\mathrm{m} 7$ & $\begin{array}{l}\text { Sınıfın kapısını örterken, kapı hareket ettiği için ona kuvvet } \\
\text { uygulamış olurum. }\end{array}$ & .545 \\
\hline $\mathrm{m} 8$ & $\begin{array}{l}\text { Temas olmadan da cisimleri itip çekebileceğimiz söyleniyor, ancak } \\
\text { buna inanmak için örnekler görmem gerekir. }\end{array}$ & .575 \\
\hline m10 & $\begin{array}{l}\text { Dünyanın merkezinin doğal bir mıknatıs olduğu fikrine inanmam için } \\
\text { daha açıklayıcı bilgilere ihtiyacım var. }\end{array}$ & .576 \\
\hline m12 & $\begin{array}{l}\text { Saçıma sürdüğüm kalemi ufak kâğıt parçalarına yaklaştırdığımda, } \\
\text { kuvvet uyguladığıma şüpheyle yaklaşırım. }\end{array}$ & .537 \\
\hline m13 & $\begin{array}{l}\text { Arkadaşlarım bazı metallerin mıknatıs tarafından çekildiğini iddia } \\
\text { ediyor; ancak buna bazı denemeler yapmadan inanmam. }\end{array}$ & .558 \\
\hline
\end{tabular}

Okuduğum bir yazıda mıknatısın sadece metalleri çektiği yazıyorsa,

m15 örnek uygulamalar görmeden bu bilginin doğruluğuna karar vermek için acele etmem.

\begin{tabular}{llc}
\hline m18 & $\begin{array}{l}\text { Bir maddenin mıknatıs tarafından çekilip çekilmediğine denemeden } \\
\text { karar vermem. }\end{array}$ & .502 \\
\hline m20 & $\begin{array}{l}\text { Öğretmenim görünmeyen kuvvetlerin hayatımızda var olduğunu } \\
\text { söylediğinde, buna inanmak için bilim insanlarının bu konudaki } \\
\text { açıklamalarını araştırırım. }\end{array}$ & .569 \\
\hline m22 & $\begin{array}{l}\text { Ders kitabı her cismi kuvvet uygulayarak hareket ettirebileceğimi } \\
\text { söylerse, bu bilgiyi başka kitaplardan da araştırma gereği hissederim. }\end{array}$ & .490 \\
\hline m23 & $\begin{array}{l}\text { Bilim Teknik dergisinde, istersek mıknatısların çekim kuvvetinin yok } \\
\text { edilebileceği yazarsa, bu açıklamayı araştırırım. }\end{array}$ & .577 \\
\hline m25 & $\begin{array}{l}\text { Miknatısların metal dışında başka maddeleri de çekebileceği fikrinin } \\
\text { doğru olma ihtimalini dikkate alırım. }\end{array}$ & .556 \\
\hline m28 & $\begin{array}{l}\text { Miknatısların kuzey ve güney kutupları dışında başka kutupları } \\
\text { olabileceğine yönelik kanıtlar varsa, bunların doğru olduğunu }\end{array}$ \\
\hline düşünebilirim.
\end{tabular}




\begin{tabular}{lll}
\hline \multirow{2}{*}{ m30 } & $\begin{array}{l}\text { Yanımdan geçen bir bisikleti yan tarafından ittiğimde, bisikletin hangi } \\
\text { yöne gideceğini merak ediyorum. }\end{array}$ & .571 \\
\hline \multirow{2}{*}{ m31 } & $\begin{array}{l}\text { Kuzey (N) ve güney (S) kutuplarına sahip iki mıknatıs ortadan ikiye } \\
\text { bölündüğünde, parçaların kutuplarının nasıl olacağını merak ederim. }\end{array}$ & .621 \\
\hline \multirow{2}{*}{ m34 } & $\begin{array}{l}\text { Teknolojik araçlarda kullanılan mıknatısların insan sağlı̆̆ üzerinde } \\
\text { etkisinin olup olmadığının, tarafsız olarak araştırılmasını beklerim. }\end{array}$ & .483 \\
\hline \multirow{2}{*}{ m36 } & $\begin{array}{l}\text { Bir mıknatısa temas ettirdiğim toplu iğnenin, bir başka toplu iğneye } \\
\text { yaklaştırdığımda da çekmesini deneylerle açıklamayı tercih ederim. }\end{array}$ & .599 \\
\hline \multirow{2}{*}{ m38 } & $\begin{array}{l}\text { Kuvvetin iş gücü ve zaman üzerindeki etkilerinin güvenilir ve test } \\
\text { edilebilir olarak sunulmasını beklerim. }\end{array}$ & .561 \\
\hline
\end{tabular}

Tablo 4. BDAÖ Ölçeğinde Yer Alan Maddeler ve Ağırlık Değerleri

Tablo 4 incelendiğinde, BDAÖ'de bulunan maddelerin ağırlık değerlerinin 0.483 ile 0.688 arasında farklılaştığı ve beklenen değerler arasında yer aldığı görülmektedir. BDAÖ’nün faktör yapısı ve açıklanan toplam varyans değeri Tablo 5'te verilmiştir.

Tablo 5. BDAÖ’ye İlişkin Faktör Yapısı ve açıklanan toplam varyans

\begin{tabular}{|c|c|c|c|c|c|c|c|}
\hline \multirow[b]{2}{*}{ Maddeler } & \multirow[b]{2}{*}{ Mantıksallık } & \multirow[b]{2}{*}{ Şüphecilik } & \multicolumn{3}{|c|}{ Otoriteden } & \multirow[b]{2}{*}{ Merak } & \multirow[b]{2}{*}{ Nesnellik } \\
\hline & & & $\begin{array}{l}\text { Askıya } \\
\text { Alınması }\end{array}$ & $\begin{array}{c}\text { Gelen } \\
\text { Argümana } \\
\text { Güvenmeme }\end{array}$ & $\begin{array}{c}\text { Açık } \\
\text { Fikirlilik }\end{array}$ & & \\
\hline $\mathrm{m} 1$ & .718 & & & & & & \\
\hline m5 & .696 & & & & & & \\
\hline $\mathrm{m} 7$ & .674 & & & & & & \\
\hline m31 & & .767 & & & & & \\
\hline $\mathrm{m} 30$ & & .612 & & & & & \\
\hline $\mathrm{m} 29$ & & .610 & & & & & \\
\hline $\mathrm{m} 20$ & & & .649 & & & & \\
\hline $\mathrm{m} 23$ & & & .649 & & & & \\
\hline $\mathrm{m} 22$ & & & .545 & & & & \\
\hline m13 & & & & .680 & & & \\
\hline
\end{tabular}


YYÜ Eğitim Fakültesi Dergisi (YYU Journal of Education Faculty), 2021; 18(2)1-24,http://efdergi.yyu.edu.tr,

\begin{tabular}{clll}
\hline $\mathrm{m} 15$ & .679 & & \\
\hline $\mathrm{m} 18$ & .653 & & \\
\hline $\mathrm{m} 28$ & & .801 & \\
\hline $\mathrm{m} 25$ & .483 & & \\
\hline $\mathrm{m} 36$ & & .748 & \\
\hline $\mathrm{m} 38$ & .643 & \\
\hline $\mathrm{m} 34$ & .543 & \\
\hline $\mathrm{m} 10$ & & .711 \\
\hline $\mathrm{m} 8$ & & & .607 \\
\hline $\mathrm{m} 12$ & & & .451 \\
\hline Aç1klanan Toplam Varyans & & 56.09 \\
\hline
\end{tabular}

Tablo 5'e göre, BDAÖ'deki maddeler yedi faktör altında düzenli dağılım göstermektedir. Faktörlere dağılan maddelerin anlam bakımından birbiriyle tutarlı olmasına dikkat edilmiş ve faktör isimlendirmeleri BDA boyutlarının anahtar özellikleri göz önüne alınarak yapılmıştır. Bu bağlamda birinci faktöre mantıksallık (m1, m5, m7), ikinci faktöre şüphecilik (m29, m30, m31), üçüncü faktöre inancın askiya alınması (m20, m22, m23), dördüncü faktöre otoriteden gelen argümana güvenmeme (m13, $\mathrm{m} 15, \mathrm{~m} 18)$, beşinci faktöre merak (m34, m36, m38), altınc1 faktöre nesnellik (m8, m10, m12) ve yedinci faktöre ise açık fikirlilik (m25, m28) isimleri verilmiştir.

\section{Doğrulayıcı Faktör Analizi}

Ölçeğin yedi faktörlü yapısının uyumunu test etmek amacıyla doğrulayıcı faktör analizinin yapılması gerektiğinden (Bayram, 2010), ölçek ikinci bir gruba (310 öğrenci) uygulanarak doğrulayıcı faktör analizi yapılmıştır (Şekil 1). 


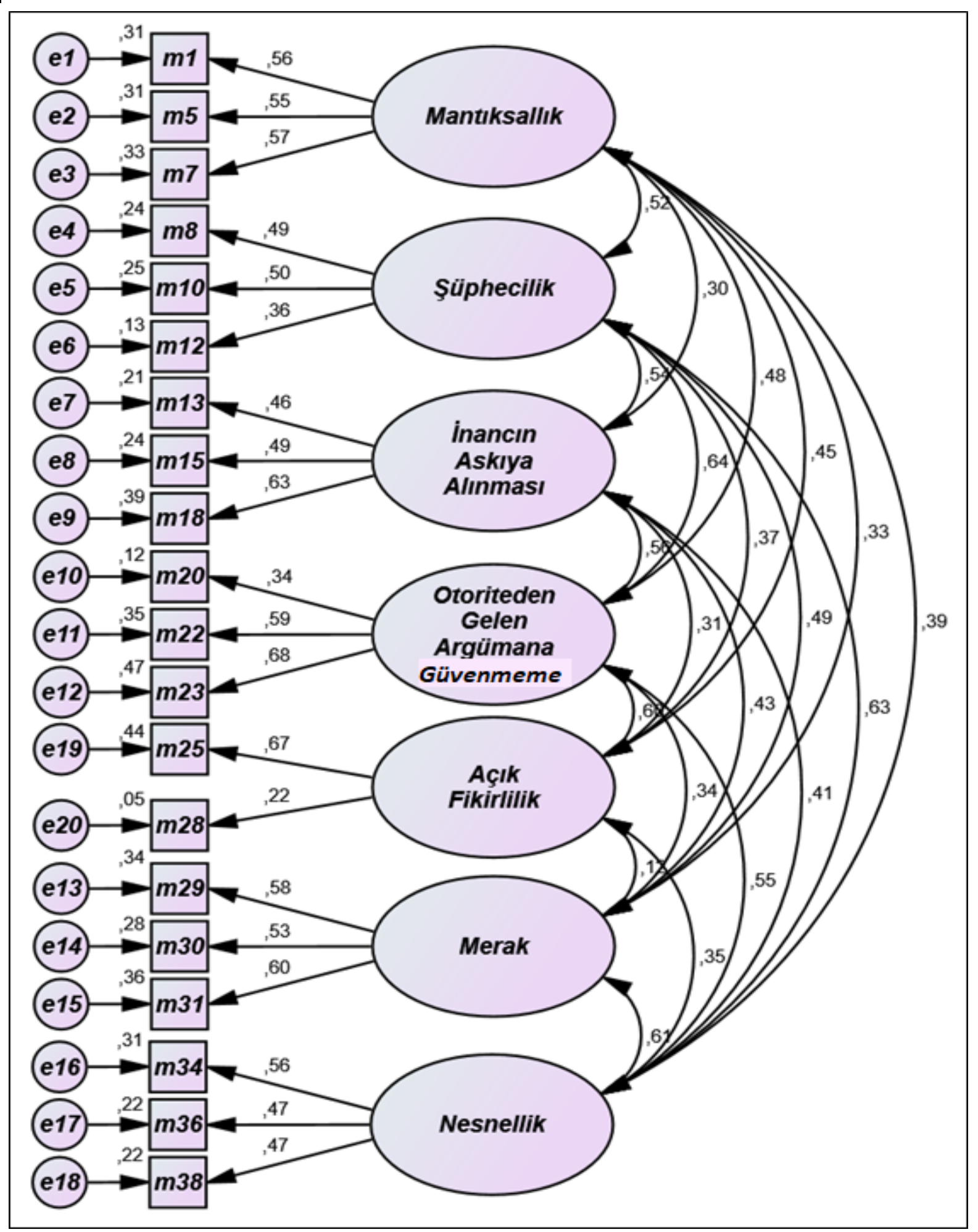

Şekil 1. BDAÖ’ye ait doğrulayıcı faktör analizi

Şekil 1'e göre, BDAÖ'nün boyutları (mantıksallık, şüphecilik, inancın askıya alınması, otoriteden gelen argümana güvenmeme, merak, nesnellik ve açık fikirlilik) ele alınarak oluşturulan model test edilmiştir. $\mathrm{Bu}$ modele ilişkin yapılan testler sonucunda, modelin uyum iyiliğinin yeterli düzeyde olduğu belirlenmiştir $(\chi 2 / d f=1.28 ; \mathrm{GFI}=0.945$; 
$\mathrm{RMSEA}=0.03 ; \mathrm{AGFI}=0.922 ; \mathrm{CFI}=0.94$ ve $\mathrm{SRMR}=0.04)$. Ölçeğin mantıksallık faktör ağırlıklarının .55 ile .57 arasında, şüphecilik faktör ağırlıklarının .36 ile .50 arasında, inancın askıya alınması faktör ağırlıklarının .46 ile .63 arasında, otoriteden gelen argümana güvenmeme faktör ağırlıklarının .36 ile .68 arasında, açık fikirlilik faktör ağırlıklarının 22 ile .67 arasında, merak faktör ağırlıklarının .53 ile .60 arasında ve nesnellik faktör ağırlıklarının .47 ile .56 arasında değiştiği görülmektedir. Ölçeğin boyutları arasındaki ilişkiye dair korelasyonlar; mantıksallık ve şüphecilik arasında .52; mantıksallık ve inancın askıya alınması arasında .30; mantıksallık ve otoriteden gelen argümana güvenmeme arasında .48; mantıksallık ve açık fikirlilik arasında .45; mantıksallık ve merak arasında .33; mantıksallık ve nesnellik arasında .39; şüphecilik ve inancın asklya alınması arasında .54; şüphecilik ve otoriteden gelen argümana güvenmeme arasında .64; şüphecilik ve açık fikirlilik arasında .37; şüphecilik ve merak arasında .49; şüphecilik ve nesnellik arasında .63; inancın askıya alınması ve otoriteden gelen argümana güvenmeme arasında .56; inancın asklya alınması ve açık fikirlilik arasında .31; inancın askıya alınması ve merak arasında .43; inancın askıya alınması ve nesnellik arasında .41; otoriteden gelen argümana güvenmeme ve açık fikirlilik arasında .65; otoriteden gelen argümana güvenmeme ve merak arasında .34; otoriteden gelen argümana güvenmeme ve nesnellik arasında .55; açık fikirlilik ve merak arasında .12; açık fikirlilik ve nesnellik arasında .35 ve merak ve nesnellik arasında .61 olarak belirlenmiştir.

\section{Güvenirlik Analizi}

Faktör analizleri sonucunda 20 madde ve yedi faktörden oluştuğu doğrulanan ölçeğin geçerlik çalışmaları tamamlanmıştır. Ardından, BDAÖ’nün ölçülen özelliği ne derece ölçtüğünü ve tutarlılık düzeyini belirlemek amacıyla güvenirlik hesaplaması yapılmıştır (Büyüköztürk, 2011). Bu işlem sonucunda, BDAÖ’nün Cronbach Alpha güvenirlik değeri .757 olarak hesaplanmış ve bu değerin $0.60 \leq \alpha<0.80$ aralığında olması sebebiyle ölçeğin yeterince güvenilir olduğu kanaatine varılmıştır (Salvucci, Walter, Conley, Fink ve Saba, 1997).

\section{Tartışma ve Sonuç}

Bu çalışmada, ilkokul 4. sınıf fen bilimleri dersi kapsamında işlenen kuvvetin etkileri ünitesine yönelik bilimsel düşünme alışkanlıkları ölçeği geliştirilerek, geçerlik ve güvenirlik çalışmaları yapılmıştır (Ek-1). Faktör analizleri sonrasında, ölçekte yer alan maddelerin yedi 
faktöre belirgin şekilde dağılım gösterdiği ve madde ağırlık değerlerinin uygun aralıklarda olduğu görülmektedir. Bu dağılım, BDA'nın alt boyutları açısından (mantıksallık, şüphecilik, nesnellik, otoriteden gelen argümana güvenmeme, inancın askıya alınması, açık fikirlilik ve merak) ölçeğin yapısal geçerliğe sahip olmasının yanında alanyazında bulunan ölçeklerle içerik ve yapısal yönden uyumlu olduğunu göstermektedir (Bağ ve Çalık, 2021; Coll ve Taylor, 2004; Wiyarsi ve Çalık, 2019). Ayrıca, yedi faktör ve 20 maddeden oluşan ölçeğin güvenirlik değerinin yüksek olması, kuvvet konularında BDA'yı ölçmek için kullanışı bir araç olduğunu göstermektedir. Diğer yandan, ölçeğin ilkokul fen bilimleri dersi kapsamındaki kuvvet konuları özelinde geliştirilmiş olmasının, BDA'nın konuya özel ölçümüne yönelik alternatif bir bakış açısı getireceği de düşünülmektedir.

Fen bilimleri dersi kapsamındaki argümantasyon ve bilimin doğası konularının bilimsel süreçleri içeriyor olması, her fen konusu üzerinden BDA'nın harekete geçirilebileceğini ve geliştirilebileceğini göstermektedir. Bu bakımdan fen konuları genelinde BDA'nın gelişimi takip edilmelidir. Mevcut çalışmada geliştirilen ölçek, BDA gelişiminin takibi açısından alanyazındaki önemli bir ihtiyaca cevap vermektedir. Buradan hareketle, mevcut araştırmada geliştirilen ölçek yardımıyla ilkokul 4. sınıf öğrencilerinin "kuvvetin etkileri” ünitesine yönelik BDA düzeyleri tespit edilebilir. Ayrıca, geliştirilen ölçek yardımıyla fen bilimleri dersi öğretim programında önerilen etkinliklerin BDA’yı nasıl geliştirdiği de araştırılabilir. Bu yolla program uzmanlarına öğretim programının çıktılarıyla ilgili dönütler verilebilir. Benzer şekilde, geliştirilen ölçekle sınıf öğretmenlerinin fen derslerinde kullandıkları etkinlik, yöntem ya da tekniklerin kendi öğrencilerinin BDA'sını nasıl etkilediğine yönelik bilgi sahibi olmaları da sağlanabilir. Diğer yandan, gelecekte bu tür BDA ölçek geliştirme çalışmaları yapmayı planlayan araştırmacıların özellikle maddelerin BDA'nın anahtar özelliklerini yansıtmasına ve konu kapsamıyla iyi bir ilişkilendirilmenin yapılmasına dikkat etmeleri önerilmektedir. Bu bağlamda, mevcut ölçek maddelerindeki denemeden karar vermem, şüpheyle yaklaşırım, merak ederim, tarafsız açıklamalar görmek isterim gibi ifadeler yeni maddelerin yazımında kullanılabilir.

\section{Makalenin Bilimdeki Konumu}

Temel Eğitim/ Fen Eğitimi

\section{Makalenin Bilimdeki Özgünlüğü}


YYÜ Eğitim Fakültesi Dergisi (YYU Journal of Education Faculty), 2021; 18(2)1-24,http://efdergi.yyu.edu.tr,

İlgili alanyazında BDA'nın genellikle sosyobilimsel konular kullanılarak incelendiği ve konu bazlı bir ölçme aracının olmadığı tespit edilmiştir. Dolayısıyla, bu çalışmada sosyobilimsel konular kullanılmadan da ilkokul dördüncü sınıf öğrencileri için konu bazlı (örneğin; kuvvetin etkileri ünitesi) bir ölçeğin geliştirilmesinin önemli bir yenilik ve özgünlük olduğu düşünülmektedir.

\section{Kaynaklar}

Aikenhead, G. S. (1985). Collective decision making in the social context of science. Science Education, 69, 453-475.

Bağ, H. and Çalık, M. (2017). A thematic review of argumentation studies at the K-8 level. Education \& Science, 42(190), 281-303.

Bağ, H. ve Çalık, M. (2018). İlkokul 4. sınıf düzeyindeki fen eğitimi araştırmalarının tematik içerik analizi. İlköğretim Online, 17(3), 1353-1377.

Bağ, H. ve Çalık, M. (2021). Maddenin özellikleri ünitesine özgü bilimsel düşünme alışkanlıkları ölçeğinin geliştirilmesi. Fen Bilimleri Öğretimi Dergisi, 9(1), 148-165.

Bayram, N. (2010). Yapısal eşitlik modellemesine giriş AMOS uygulamaları. İstanbul: Ezgi Kitabevi.

Bursal, M. (2019). Ortaokul öğrencilerinin fen derslerinde kullanılan grafiklere yönelik bazı duyuşsal özelliklerini ölçme araçları geliştirme. Online Fen Eğitimi Dergisi, 4(1), 2043.

Büyüköztürk, Ş. (2011). Sosyal bilimler için veri analizi el kitabl (17. bask1). Ankara: Pegem Akademi.

Bybee, R., McCrae, B., \& Laurie, R. (2009). PISA 2006: An assessment of scientific literacy. Journal of Research in Science Teaching, 46(8), 865-883.

Candaş, B., Kıryak, Z., Kılınç, A., Güven, O. ve Özmen, H. (2019). 2013 ve 2018 fen bilimleri öğretim programlarının genel eğilimler ve yaklaşımlar açısından karşılaştırılması. Yüzüncü Yll Üniversitesi Eğitim Fakültesi Dergisi, 16(1), 1668-1697.

Coll, R. K., \& Taylor, N. (2004). Probing scientists' beliefs: How open-minded are modern scientists?. International Journal of Science Education, 26(6), 757-778.

Çalık, M. \& Cobern, W. W. (2017). A cross-cultural study of CKCM efficacy in an undergraduate chemistry classroom. Chemistry Education Research and Practice, 18(4), 691-709. 
Çalık, M. \& Coll, R. K. (2012). Investigating socioscientific issues via scientific habits of mind: Development and validation of the scientific habits of mind survey (SHOMS). International Journal of Science Education, 34(12), 1909-1930.

Çalık, M., \& Karatas, F. Ö. (2019). Does a" science, technology and social change" course improve scientific habits of mind and attitudes towards socioscientific issues?. Australian Journal of Teacher Education, 44(6), 35-52.

Çalık, M., Turan, B., \& Coll, R. K. (2014). A cross-age study of elementary student teachers’ scientific habits of mind concerning socioscientific issues. International Journal of Science and Mathematics Education, 12(6), 1315-1340.

Ecevit, T. ve Kaptan, F. (2019). 21. yüzyıl becerilerinin kazandırılmasına yönelik tasarlanan argümantasyon destekli araştırma-sorgulamaya dayalı öğretim modelinin betimlenmesi. Hacettepe Üniversitesi Eğitim Fakültesi Dergisi. Advance online publication.

Elby, A. \& Hammer, D. (2001). On the substance of a sophisticated epistemology. Science Education, 85, 554-567.

Erduran, S. and Jimenez-Aleixandre, M. P. (2007). Argumentation in science education: Recent development and future directions. Dordrech: Springer.

Fraenkel, J. R. \& Wallen, N. E. (1996). How to design and evaluate research in education. USA: Von Hoffmann Press.

Gauld, C.F. (1982). The scientific attitude and science education: A critical reappraisal. Science Education, 66, 109-121.

Gauld, C.F. (2005). Habits of mind, scholarship and decision making in science and religion. Science and Education, 14, 291-308.

Hare, W. (1987). Russell's contribution to philosophy of education. Russell, 7(1), 25-41.

Hare, W. (2003). Is it good to be open-minded? The International Journal of Applied Philosophy,

Holton, G. (1978). The scientific imagination: Case studies. Cambridge, UK: Cambridge University Press.

Hodson, D. (2003). Time for action: Science education for an alternative future. International Journal of Science Education, 25(6), 645-670.

Kalayc1, Ş. (2010). SPSS uygulamalı çok değişkenli istatistik teknikleri (5. baskı). Ankara: Asil Yayın Dağıtım.

Kolomuç, A. ve Çalık, M. (2019). Öğretim elemanlarının sosyobilimsel konulara yönelik bilimsel düşünme alışkanlıklarının karşılaştırılması. Yükseköğretim Dergisi, 9(1), 67-74. 
Kolstø, S.D., Bungum, B., Arnesen, E., Isnes, A., Kristensen, T., Mathiassen, K. \& Ulvik, M. (2006). Science students' critical examination of scientific information related to socioscientific issues. Science Education, 90, 632-655.

Koyuncu, İ. ve Kılıç, A. F. (2019). Açımlayıcı ve doğrulayıcı faktör analizlerinin kullanımı: Bir doküman incelemesi. Eğitim ve Bilim, 44(198), 361-388.

Krajcik, J. and McNeill, K. L. (2015). Designing and assessing scientific explanation tasks. In R. Gunstone (Ed.), Encyclopedia of science education, 285-290. Dordrecht, The Netherlands: Springer.

Küçük, M. (2006). Bilimin doğasını ilköğretim 7. sınıf öğrencilerine ögrretmeye yönelik bir çalışma. (Yayımlanmamış Doktora Tezi). Karadeniz Teknik Üniversitesi, Fen Bilimleri Enstitüsü, Trabzon.

Lederman, L.M. (1998). ARISE: American Renaissance in Science Education. FERMILABTM- 2051. Retrieved from http://finalpubs.final.gov/archive/1998/tm/TM205.pdf

Milli Eğitim Bakanlığı (MEB) (2018). İlköğretim kurumları (ilkokullar ve ortaokullar) fen bilimleri dersi $(3,4,5,6,7$ ve 8 . sınıflar) öğretim programı, Ankara: Milli Eğitim Bakanlığı.

Rutherford, F.J., \& Ahlgren, A., 1990. Science for All Americans. Oxford University Press, New York.

Sağdıç, M., Bakırcı, H. ve Boynukara, Z. (2019). Rehberli sorgulama öğretim modeline dayalı fen öğretiminin 7. sınıf öğrencilerinin bilimsel süreç becerileri üzerindeki etkisinin incelenmesi: Kuvvet ve enerji ünitesi örneği. Yüzüncü Yıl Üniversitesi Eğitim Fakültesi Dergisi, 16(1), 943-959.

Salvucci, S., Walter, E., Conley, V., Fink, S., \& Mehrdad, S. (1997). Measurement error studies at the National Center for Education Statistics (NCES 97-464). Washington, DC: National Center for Education Statistics

Stanley, W.B. \& Brickhouse, N.W. (1996). Multiculturalism, universalism, and science education. Science Education, 78(4), 387-398.

Storer, N.W. (1966). The social system of science. New York, NY: Holt, Rinehart \& Winston.

Uluçınar-Sağır, Ş. ve Kılıç, Z. (2013). İlköğretim öğrencilerinin bilimin doğasını anlama düzeylerine bilimsel tartışma odaklı öğretimin etkisi. Hacettepe Üniversitesi Eğitim Fakültesi Dergisi, 44(44), 308-318. 


\section{avill 0 ne \\ YYÜ Eğitim Fakültesi Dergisi (YYU Journal of Education Faculty), 2021; 18(2)1-24,http://efdergi.yyu.edu.tr,

Wiyarsi, A. \& Çalik, M. (2019). Revisiting the scientific habits of mind scale for socioscientific issues in the Indonesian context. International Journal of Science Education, 41(17), 2430-2447. 


\section{avill 0 ni

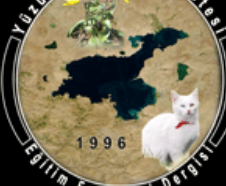 \\ YYÜ Eğitim Fakültesi Dergisi (YYU Journal of Education Faculty), 2021; 18(2)1-24,http://efdergi.yyu.edu.tr,

Ek-1. Bilimsel Düşünme Alışkanlıkları Ölçeği 
Sevgili öğrenciler,

Kuvvetin Etkileri Ünitesine Ait Bilimsel Düşūnme Alışkanlıkları Ölçeği

Așağıdaki ölçek, birinci dönem ișlediğiniz "Kuvvetin Etkileri" ünitesini kapsamaktadır. Bu ölçek yardımıyla, sizlerin bilimsel dūșünme alışkanlıklarınızı belirlemeyi amaçlıyoruz. Bu ōlçekten, herhangi bir puan almayacaksııız; bu nedenle "Doğru" ya da

"Yanlış" cevap yoktur. Ölçekteki ifadeler yūz ifadeleriyle 4 șekilde derecelendirilmiştir. Maddelere ait düşūncelerinizi bu

ifadeler ūzerine işaretlemenizi rica ediyoruz. Her bir yūz ifadesinin anlamı așağıda verilmiștir.

Kesinlikle katılmıyorum

Katılmıyorum

Katiliryorum

Kesinlikle katıliyorum

Maddeler

1. Oyuncak bir arabayı iterek oynadığımda, onu kuvvetin yönü doğrultusunda hareket ettirdiğim için kuvvet uygulamıs olurum.

2. Bir kalecinin topu huzlı ya da yavaș yuvarlaması, topa uyguladığı kuvvete bağlıdır.

3. Sunufın kapısunı örterken, kapı hareket ettiği için ona kuvvet uygulamıs olurum.

4. Temas olmadan da cisimleri itip çekebileceğimiz söyleniyor, ancak buna inanmak için örnekler görmem gerekir.

5. Dünyanun merkezinin doğal bir mıknatıs olduğu fikrine inanmam için daha açıllayıcı bilgilere ihtiyacım var.

6. Saçıma sürdüğüm kalemi ufak kâğıt parçalarına yaklaștırdığımda, kuvvet uyguladığıma șüpheyle yaklașınm.

7. Arkadaşlanm bazı metallerin mıknatıs tarafından çekildiğini iddia ediyor; ancak buna bazı denemeler yapmadan inanmam.

8. Okuduğum bir yazıda mıknatısın sadece metalleri çektiği yazıyorsa, ömek uygulamalar görmeden bu bilginin doğruluğuna karar vermek için acele etmem.

9. Bir maddenin mıknatıs tarafmndan çekilip çekilmediğine denemeden karar vermem.

10. Öğretmenim görünmeyen kuvvetlerin hayatımızda var olduğunu söylediğinde, buna inanmak için bilim insanlannun bu konudaki açıklamalannı araștırınm.

11. Ders kitabı her cismi kuvvet uygulayarak hareket ettirebileceğimi söylerse, bu bilgiyi bașka kitaplardan da araștırma gereği hissederim.

12. Bilim Teknik dergisinde, istersek mıknatıslann çekim kuvvetinin yok edilebileceği yazarsa, bu açıklamayı araștırınm.

13. Mıknatıslann metal dıșmda bașka maddeleri de çekebileceği fikrinin doğru olma ihtimalini dikkate alınm.

14. Mıknatıslann kuzey ve güney kutuplan dıșında bașka kutuplanı olabileceğine yönelik kanutlar varsa, bunları doğru olduğunu düșünebilirim.

15. Kuvvetin hayatımızdaki etkilerini merak ediyorum.

16. Yanumdan geçen bir bisikleti yan tarafından ittiğimde, bisikletin hangi yöne gideceğini merak ediyorum.

17. Kuzey $(\mathrm{N})$ ve güney (S) kutuplanna sahip iki muknatıs ortadan ikiye bölündü ğünde, parçaların kutuplarınun nasıl olacağını merak ederim.

18. Teknolojik araçlarda kullanılan mıknatısların insan sağhğı üzerinde etkisinin olup olmadığınun, tarafsız olarak araștırılmasınu beklerim.

19. Bir mıknatısa temas ettirdiğim toplu iğnenin, bir bașka toplu iğneye yaklaștırdığımda da çekmesini deneylerle açıklamayı tercih ederim.

20. Kuvvetin iṣ gücü ve zaman üzerindeki etkilerinin güvenilir ve test edilebilir olarak sunulmasun beklerim.

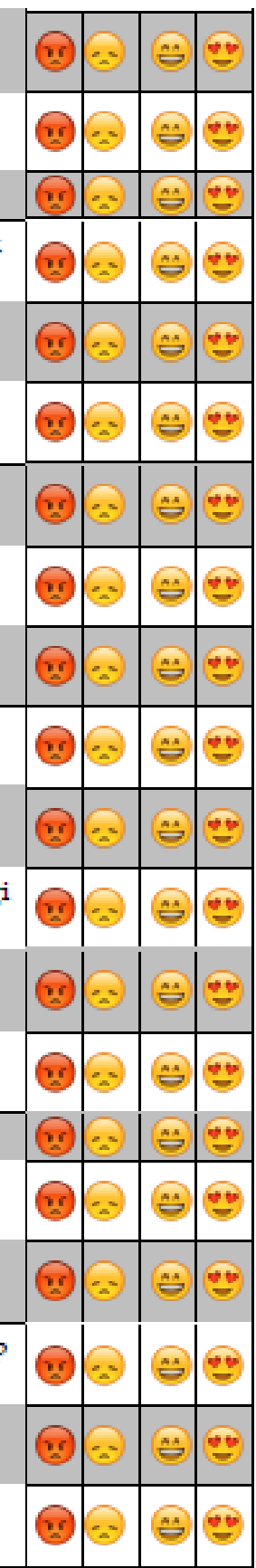

\section{Summary}




\section{Statement of Problem}

Rapid advances in science and technology have fostered science educators and curriculum developers to make more emphasis on the concept "scientific thinking" in science curricula. For example, 2018 Science Curriculum in Turkey purposes to develop reasoning abilities, scientific habits of mind (SHOM) and decision-making skills via socioscientific issues. Thus, it calls for enriched learning environments that engage students in inquiry-based science activities to improve their higher order thinking skills (e.g., nature of science, cooperation, science process skills, argumentation, reasoning abilities, scientific habits of mind, etc.) (Bağ \& Çalık, 2017; Bybee, McCrae, \& Laurie, 2009; Ecevit \& Captain, 2019; Küçük, 2006). Because scientific habits of mind (SHOM) are highly related to higher-order thinking skills, SHOM plays a significant role at achieving scientific literacy (Çalık \& Coll, 2012). Early studies showed that some of SHOM were predominantly developed for the upper schooling levels (Çalık et al., 2014; Çalık \& Cobern, 2017; Çalık \& Karataş, 2019; Kolomuç \& Çalık, 2019). This means that students' SHOM levels should be identified at early ages, e.g., primary school, to develop a better scientific literacy. Even though relevant literature has included various SHOM scales, which were developed and validated for pre-service teachers and adults (lay people), none of them has been adapted into primary school to elicit their SHOM levels. Moreover, since the existing SHOM scales mainly deploy socioscientific issues to measure the SHOM levels (Çalık \& Coll, 2012; Wiyarsi \& Çalık, 2019), the current study inquiries whether the SHOM levels can be measured via science topics, e.g., the 'effects of force' unit. For this reason, the aim of this study was to develop the scientific habits of minds (SHOM) scale for the 'effects of force' unit in grade 4 science course.

\section{Method}

To develop the SHOM scale, the authors initially looked over related literature and key features of SHOM. Next, they examined the goals of the 'effects of force' unit, science textbooks and previous SHOM scales (Çalık \& Coll, 2012; Wiyarsi \& Çalık, 2019) to generate an item pool. Thus, a 38-item SHOM scale with 4-point-Likert type appeared. A group of experts reviewed the items in terms of content validity. The authors revised the items in regard to the experts' comments/feedbacks and administered the scale to two different groups (310 by 310) for exploratory and confirmatory factor analysis.

\section{Findings}


As seen from Table 3, the KMO value was calculated to be 0.711 . This means that the scale was suitable for the exploratory factor analysis. In this process, the authors removed some items, whose item loadings were below 0.30 and randomly distributed to the factors. The exploratory factor analysis indicated that 20 items had sufficient weight values and fell into 7 factors (see Tables 4-5). The indices of the confirmatory factor analysis were as follows: $\chi 2 / d f=1.28$; $\mathrm{GFI}=0.945$; RMSEA=0.03; $\mathrm{AGFI}=0.922 ; \mathrm{CFI}=0.94$ and $\mathrm{SRMR}=0.04$ (see Fig. 1). In addition, the Cronbach Alpha coefficient was found to be 0.757 meaning that the scale is reliable.

\section{Discussion and Conclusion}

Because the exploratory and confirmatory factor analysis revealed seven factors (rationality, skepticism, suspension of belief, mistrust of argument from authority, curiosity, objectivity, open-mindedness) with suitable item loadings and indices, the current study concludes that the scale has a proper construct validity. Further, the current scale is also consistent with the previous SHOM scales (Coll \& Taylor, 2004; Wiyarsi \& Çalık, 2019). In addition, since the scale possessed an acceptable reliability value, the authors offer that it is a useful tool to measure the primary school students' SHOM levels. To sum up, because the scale was specifically developed for the primary school students by means of the 'effects of force' unit, it proves that the SHOM can alternatively be measured via science topics/units (as content knowledge) without the use of socioscientific issues.

The SHOM scale developed in the present study fills in an important gap in the related literature. Thereby, future studies may use this scale to determine grade 4 students' SHOM levels of the "effects of force" unit. In addition, further studies should be undertaken to investigate how science activities suggested by 2018 science curriculum improve the SHOM. By doing this, such studies give invaluable feedbacks for curriculum developers about the learning outcomes of the science curriculum. 